\title{
Utilization of national health insurance for family planning and reproductive health services by the urban poor in Uttar Pradesh, India
}

The Evidence Project

Follow this and additional works at: https://knowledgecommons.popcouncil.org/departments_sbsr-rh

Part of the Demography, Population, and Ecology Commons, Family, Life Course, and Society Commons, Health Policy Commons, International Public Health Commons, and the Women's Health Commons How does access to this work benefit you? Let us know!

\section{Recommended Citation}

"Utilization of national health insurance for family planning and reproductive health services by the urban poor in Uttar Pradesh, India," Activity brief. Washington, DC: The Evidence Project, 2015. 


\section{Utilization of National Health Insurance for Family Planning and Reproductive Health Services by the Urban Poor in Uttar Pradesh, India}

\section{ACTIVITY BRIEF}

In 2008, the Government of India launched the National Health Insurance program, Rashtriya Swasthya Bima Yojana (RSBY), to enable families living below the poverty line in urban and rural areas to access a range of private health services. Enrolled families can avail pre-specified packages of services from RSBY participating private hospitals, including for family planning (FP) and other reproductive health $(\mathrm{RH})$ services (see other side).

Despite the availability of insurance coverage, poor families' utilization of RSBY for FP/RH services is believed to be negligible.

\section{THE STUDY}

The Evidence Project is conducting a study in three cities in Uttar Pradesh to better understand the supply and demand factors affecting the utilization of RSBY for FP/RH services. The study is timely, as the government is eager to increase the number of beneficiaries, their uptake of health services, and the number of private hospitals participating in the program. The study is also important given that RSBY is operating in an expanding urban environment, where there is a rapidly growing need for $\mathrm{FP} / \mathrm{RH}$ services among the urban poor. The findings from this study will help contribute to India's FP2020 goals by ensuring that high quality $\mathrm{FP} / \mathrm{RH}$ services are available to the most disadvantaged groups.

\section{STUDY OBJECTIVES}

1. Determine the level of awareness about RSBY and the barriers in enrolling in RSBY among the urban poor.

2. Identify the barriers and facilitating factors faced by enrolled families in utilizing RSBY for FP/RH services.

3. Assess the concerns and limitations of RSBY participating private hospitals in providing $\mathrm{FP} / \mathrm{RH}$ services to the urban poor under RSBY.

4. Provide programmatic recommendations for national and state governments to help improve the delivery and utilization of RSBY for FP/RH services.
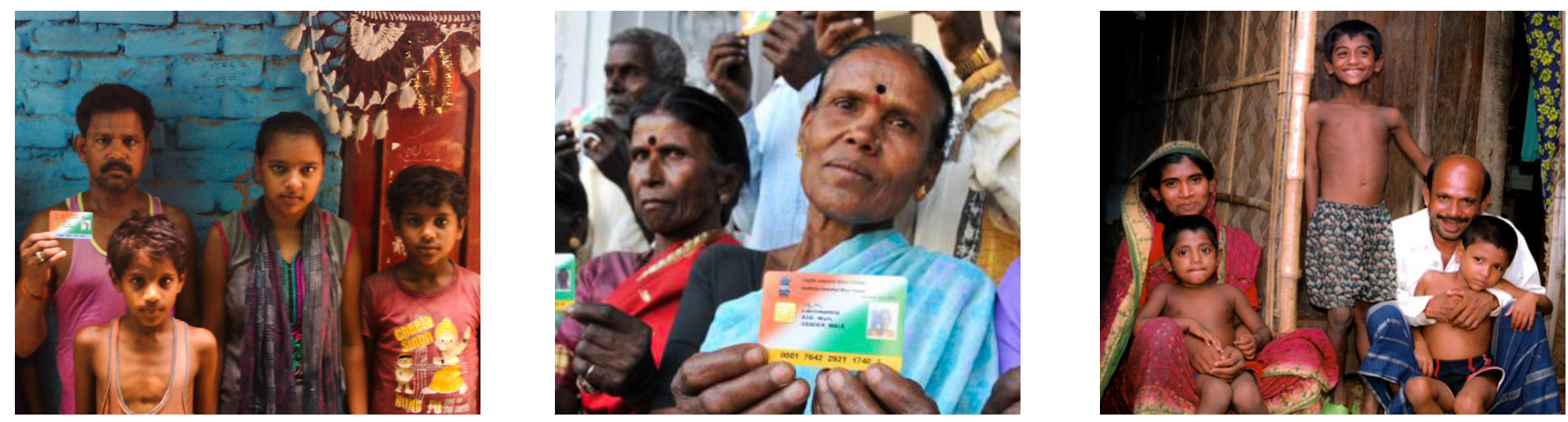


\section{STUDY DESIGN}

This cross sectional study uses both quantitative and qualitative data collection methods. To identify RSBY participating and non-participating families, the researchers are screening households living below the poverty line in urban slums in the three cities. This is enabling the researchers to find out about the level of awareness of RSBY and to draw a survey sample of 800 married women aged 18-35 years participating in the program and 800 adult males of the same families, either the women's husband or the household head.

In-depth interviews are also being conducted with women from families enrolled in RSBY as well as the heads and health care providers of RSBY participating private hospitals to understand their experiences in utilizing and in providing RSBY for FP/RH services, respectively. Additionally, focus group discussions among men from families not enrolled in RSBY are being held to understand why some families do not enroll in RSBY. Further, a few program managers and insurance company representatives are being interviewed to understand the changes in the policy environment around RSBY and their views on utilization of RSBY for FP/RH services.

\section{RSBY FP/RH SERVICES EXAMINED}

\begin{tabular}{ll}
\hline FP Services & - IUD insertion \\
- Tubal ligation (female sterilization) \\
- Vasectomy (male sterilization) \\
RH Services & - Labor and delivery \\
- Pregnancy and delivery complications & (e.g. caesarean, hysterectomy) \\
- Post-abortion complications
\end{tabular}

This study will provide quantitative data on RSBY families' level of awareness on the availability of FP/ $\mathrm{RH}$ services from participating private hospitals, their utilization of RSBY for $\mathrm{FP} / \mathrm{RH}$ services, the challenges they face in availing RSBY services, the reasons they do not utilize RSBY for FP/RH services, and unmet need for contraception among RSBY families.

The qualitative data will provide a more in-depth understanding of the reasons why families do not enroll in RSBY, why women choose or do not choose RSBY for $\mathrm{FP} / \mathrm{RH}$ services, and their experience in accessing these services. Further, the study will capture the experiences and views of health providers of participating hospitals and insurance companies in providing $\mathrm{FP} / \mathrm{RH}$ services under RSBY and their recommendations to increase utilization.

\section{RESEARCH UTILIZATION}

The study will generate important evidence on the challenges and implementation gaps in delivering and utilizing RSBY for $\mathrm{FP} / \mathrm{RH}$ services and will provide decisionmakers with actions to mitigate them. The Evidence Project will hold a series of meetings to discuss the findings and their implications with policy makers at the national and state level, representatives of the technical support unit set up by the Bill and Melinda Gates Foundation in Uttar Pradesh, USAID and other development partners, NGOs/INGOs, and other stakeholders. In addition, the findings will be presented in relevant national, regional, and international forums and conferences and published in a peer reviewed journal to reach the scientific community.

\section{Evidence \\ The Evidence Project is led by the Population Council in partnership with INDEPTH Network, International Planned Parenthood Federation, Management Sciences for Health, PATH, Population Reference Bureau, and a University Research Network. Other partners are FHI360, Meridian Group International, Inc., and What Works Association.}

The Evidence Project is made possible by the generous support of the American people through the United States Agency for International Development (USAID) under the terms of cooperative agreement no. AID-OAA-A-13-00087. The contents of this document are the sole responsibility of the Evidence Project and Population Council and do not necessarily reflect the views of USAID or the United States Government.

For more information, go to evidenceproject.popcouncil.org

or contact Kumudha Aruldas at akumudha@popcouncil.org or Arupendra Mozumdar at amozumdar@popcouncil.org 